\title{
Surfaces
}

\section{Introduction to and Discussion Summary of Ching-hsien Wang's "Cheng Hsuan Awakened from a Dream"}

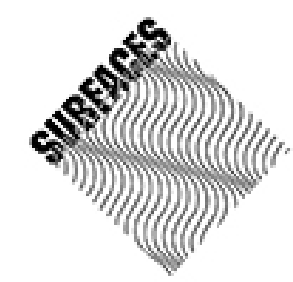

\section{Hazard Adams}

Volume 5, 1995

DEUXIÈME CONGRÈS INTERNATIONAL SUR LE DISCOURS HUMANISTE (1995)

SECOND INTERNATIONAL CONFERENCE ON HUMANISTIC

DISCOURSE (1995)

URI : https://id.erudit.org/iderudit/1064995ar

DOI : https://doi.org/10.7202/1064995ar

Aller au sommaire du numéro

Éditeur(s)

Les Presses de l’Université de Montréal

ISSN

1188-2492 (imprimé)

1200-5320 (numérique)

Découvrir la revue

Citer ce document

Adams, H. (1995). Introduction to and Discussion Summary of Ching-hsien Wang's "Cheng Hsuan Awakened from a Dream". Surfaces, 5.

https://doi.org/10.7202/1064995ar
Résumé de l'article

Dans le cadre du deuxième congrès international sur le discours humaniste, ce texte est une introduction à "Cheng Hsuan réveillé d'un rêve " de Ching-hsien Wang, et rapporte les principaux pôles d'intérêt qui ont émergé au cours de la discussion. 


\section{Introduction to and Discussion Summary of Ching-hsien Wang's}

\section{"Cheng Hsuan Awakened from a Dream"}

Hazard Adams

Surfaces Vol.V.204.1 (v.1.0A - 31/12/1995)

Copyright for texts published in SURFACES remains the property of authors. However, any further publication should be accompanied by an acknowledgement of SURFACES as the place of initial publication.

ISSN: $1188-2492$

\section{ABSTRACT}

In the context of the Second International Conference on Humanistic Discourse, this text introduces Ching-hsien Wang's "Cheng Hsuan Awakened from a Dream" and reports on the central concerns that emerged in its discussion.

\section{RÉSUMÉ}

Dans le cadre du deuxième congrès international sur le discours humaniste, ce texte est une introduction à "Cheng Hsuan réveillé d'un rêve" de Chinghsien Wang, et rapporte les principaux pôles d'intérêt qui ont émergé au cours de la discussion.

Hazard Adams introduced Ching-hsien Wang's poem with the following remarks:

"This paper (or rather, poem) raises a number of questions and possible comments. I shall divide mine into five parts:

1) This is a poem written under a pseudonym (Yang $\mathrm{Mu}$ ) and has another title in an earlier version. It is a poem translated from the Chinese by the author, but not under the pseudonym. It is a poem in translation put to a new purpose, that of this conference, whatever that may be. It is a poem annotated by the author under the name of $\mathrm{C}$. H. Wang. 
"Some of the questions are as follows: What is the role of a pseudonym? Are the roles different in East and West? There is the question of translatability. There is the question of the author as translator of his own work, and in this case, into a language that is not his first language. There is a question of what a title is. There is a question of what the annotations are doing and whether they are part of the poem or not. Here they seem to be mainly historical in character.

2) "How are we to deal with a poem in this conference context? As a verse essay, like Pope' s Essay on Criticism? Clearly it isn' t that. Should we deal with it as if it were presented to us as a problem in translation? Given the title and its circumstances, this is apparently not its purpose, though so to treat it would certainly be germane to our discusssions following the essay we have just discussed. Should we treat it as if it were presented as a didactic assertion of an ideological view? But this makes us convert it into a verse essay. Should we treat it as a verbally constituted moment for meditation or speculation? This is more likely. That can eventuate in interpretation by way of conversation.

3) "And so, a few paraphrastic remarks just to orient myself if no one else. On a spring night after wine, the Confucian exegete Cheng Hsuan is awakened by the spirit of Confucius, who, in character, taps him on the foot with a cane and warns him of difficult years ahead. He looks outside, sees a blossoming tree, and imagines the struggle going on at Commissionerford (a wonderful name, I might add). He directs himself to arise with Confucian spirit, apparently to a recognition of conflict.

"He reflects on the position he once held. Though the great King Wen seemed to have an unusual power to settle differences, even before having to intervene in them, he was not able to bring litigations to completion, or rather, one always led to another. And, besides, the great Wen is long dead. Somehow he, himself, is still the shameful public functionary. He considers that there might be some " perfect measures" that would work to produce a social value. (A pun here, I think, in English at any rate: economic and political measures as against the measures of poetry, both being associated with Confucian tradition, where all is properly measured).

"He recalls also that the poet Ma Jung one evening called on him for his expertise, but by that time his study of those things, which occurred in the West of China, was ending, and Ma Jung recognized that his own way, that of thought, would go with him. That way was the Mao tradition after some dalliance he had had with a system of comparative hermeneutics. He developed his skill in each of the four parts of the Confucian curriculum: literary study (philology), virtue, government, and oratory.

"He then declares his strength in each of these areas, with some barbs directed at some Confucian predecessors and assertions of his withdrawal from certain worldly opportunities in order to farm and attend to scholarship. He feels he has done pretty well in virtue; he did expound government to Ma Jung; in an exhibit of oratory, he rejected a bureaucrat as a student. There is a certain irony directed more than one way in what he says. 
"He is now old. His life, as he has expressed it, has been like a timber beam; it has produced much, like the burst of spring outside his window, and his scholarship contains China' s turbulent history. There is trouble ahead, and death. An oracle.

"I apologize for this paltry paraphrase. I do not know how accurate it is. I have no idea what Ching-hsien Wang (Yang $\mathrm{Mu}$ ) is going to say about it.

4) "This poem seems to me a testament to a certain intellectual tradition that privileges the poet as scholar. But it warns against some things that can happen in the Confucian tradition even as it reaffirms it. It warns, I think, against, or perhaps it rejects, one of the four parts of the curriculum--not virtue, not literary study, not oratory (it could be said to be itself a mimesis of the last). It opposes, a better word than " rejects," government and what it implies goes with it: bureaucracy, planning (of a sort), and all that neatness which ends up being so messy. It speaks for the virtue of literary study, which includes of course, the writing of poetry; with a certain wryness, suggesting that it, too, cannot bring its kind of litigation to closure except with the poet's death. There is still the year of the dragon and the year of the snake, also the lovely spring morning of the present, also the ending of death. Much to be loved, much to be deplored, and the end.

5) "Poems bring us together, but without compromises, and on their terms. This poem speaks, I think, for all of us in some way that is humanistic, East or West. Or at least we can imagine this. We inhabit two places (maybe more) at once: Cheng Hsuan' s mind, our own mind observing his. Same and different at the same time: The stance of virtue as the poet constructs it; the poet as other to us and the world; the poet as same in his otherness.

"So this paper, or anti-paper, raises questions and performs a function. The function is to provide a continuing opposed commentary, to assert the poetic art against our own humanistic and other techniques. In that it is a continual warning. It raises, as I have said before, the question of translation, and in this case from one culture to another, and perhaps C. H. Wang will comment on Yang $\mathrm{Mu}$, or Yang $\mathrm{Mu}$ will comment on C. H. Wang.

"It raises more importantly, I think, the question of what role the poet or poems or respect or disrespect for poetry play in our various cultures. I think this question will lead to our thinking about differences, about change in the relation of poetry to cultures. It also seems to me that we may have to decide that poetry simply opposes the whole enterprise of humanistic discourse as we think about it academically, or perhaps poetry is continually deflecting it, or trying to do so."

Prof. Wang then read the poem in Chinese.

Discussion began with attention to the poem's various dimensions and quickly turned to the problem of translation with respect both to specific words and phrases and to the question of translation between cultures. Prof. Wang discussed how his reading of the translation seemed to reveal a changed persona. Prof. Lee noted that there were no footnotes in the Chinese version and queried how to negotiate the difference, alluding to some similarity to T. S. Eliot's use of footnote and allusion. Prof. Krieger 
recognized the poem by way of his experience of Browning' s dramatic monologues, and Prof. Adams observed that there was no specifically implied listener as there was in Browning. Prof. Miller noted the Cantos of Pound and the presence of history in the poem in the way that he thought not possible in American poetry or even Browning, who might go as far back as the Renaissance, but hardly farther, whereas in this poem there is a much greater sweep of time and tradition involved. Prof. Yu remarked first that the footnotes would not seem esoteric or even erudite to a Chinese reader and second that the poem is so thoroughly embedded in an intellectual tradition that it is difficult to see it as oppositional to humanistic discourse generally. She asked what Wang intended with respect to government and politics. Wang replied as follows: "In Confucius' s day it was thought that if it' s possible to contribute to government we do that, but if it' $s$ impossible we hide ourselves and cultivate inwardly to prepare ourselves in a better way for the day when the chance is right. Then we come out again. At the end of the Han dynasty it was a typically chaotic time, so to go to cultivate scholarship and plow the land was a more meaningful thing that just to preserve fame or wealth or whatever in the government."

Prof. Iser followed up on the question of translation by considering what he called " cultural noise," which is made by way of interpretation from the situation of untranslatability and is often quite distorting. He spoke of what seemed to him a deliberate untranslatability in the poem. There followed discussion of the relation of the two versions, and Prof. Lee suggested the possibility of a "bilingual" reading.

Prof. Lin, with respect to the question of the role of Confucianism, remarked that since about 1970, with the rise of a new consciousness in Taiwan one heard it declared that some poems were too good in the sense of connection to tradition, that there was impatience with this goodness, and he held that humanistic discourse engages poetry in China, implying the importance of this engagement as political. Prof. Krieger suspected that this poem would not be regarded as sufficiently political by many politically oriented readers. Prof. Wang, briefly repeating the gist of his earlier remarks, implied that his poem was political against politics, the poet needing to resist a terrible situation by having nothing to do with it. Prof. Lin spoke further of poetry' s and scholarship' s involvement in Confucian tradition. Confucius himself engaged in political activity, with the aim of bringing peace and prosperity to the world and noted that to be a magistrate one had to pass an examination in poetry. But Prof. Lee warned against what seemed to him a grave danger of oversimplification when one engaged in a hermetically sealed local interpretation which says that the poem can only be subject to a local political reading. He saw the poem as intricately involved with a cultural tradition. He argued that the whole purpose of the present discussion was to sort out intricacies rather than to simplify. He argued further that the poem, no matter what the poet intended to do, even in the Chinese version, was more than local, it was in the area of " world poetry" (a term of Steven Owen). Finally he asserted that the poem was not based on the knowledge of Confucian teaching that one brings to it, but that it incorporates that in a certain way. /pp. 9-10/ 
Prof. Pfeiffer raised the question of what the status of poetry was in a Chinese political culture and how it might be shifting. The question was briefly buried in a continued discussion of the role of the aspiring magistrate' s study of poetry in order to become a government official in classical China, but Pfeiffer's question influenced much subsequent discussion.

Prof. Adams remarked that Prof. Wang had once said to him that he was an anarchist, but Prof. Adams did not think of Prof. Wang' s statement as political in the usual sense; Prof. Wang had spoken of withdrawal to wait for the right moment, but for the modern poet, which Yang Mu certainly was, can that moment ever occur? Doesn' t the poet now always have to be elsewhere to the dominant political cuture and even to those in political opposition? Isn' t that " elsewhere" a constant critique of political culture, and one that will not play the same language games?

Prof. Wang agreed and repeated that his poem says that for his speaker scholarship is more important than political participation.

The question arose as to what the poet's relation to Chinese or Taiwanese culture was today. Prof. Wang remarked that the role of the poet greatly varied from poet to poet, but in general it was a little different today from the role as Prof. Lin described it in ancient Chinese culture. Some poets today would not accept allegience to the Confucian tradition, and not just because they were of a younger generation.

Prof. Tay then shifted discussion to the question of the reception of poems, remarking that most of the poems written by magistrates were regarded as bad. He also observed that the Chinese have the tradition of the literary supplement in the daily newspapers, which includes poems and scholarly and philosophical essays. This was not to his knowledge a Western phenomenon. Poetry thus plays a role in Taiwan' s public culture even if only, say, 5,000 of the $1,000,000$ readers pay attention to those pages. There is engagement and intervention in current matters. Even in very commercial Hong Kong there is a literary page maintained by one paper /pp. 10-11/ and columns written by literary figures in others, and editors do not interfere with their content. So poets do play some public role there.

Prof. Lin insisted on the interrelation of scholarship, poetry, and politics. But Prof. Lee observed that poetry became an alternative to government service in the early modern period and that the Confucian tradition was complex and varied with a range of poetry from private to public. In modern times the poet was alienated from political bureaucracy.

Prof. Wang then asked the question: Was his poem part of humanistic discourse? Prof. Iser replied that we drag the poem into humanistic discourse by translating it into cognitive terms. The poem is noncognitive. Our act is alien to poetic discourse, a concession to readership, but sometimes this translation is obscure to readers. Prof. Krieger observed that he saw in this remark a repetition of the ancient war between poets and philosophers, and Prof. Adams declared that these are two necessary sides of the same coin. Prof. Krieger also observed that some postmodern philosophy tries to come over to the poetic in a sort of self-subversion. 
The question of what poetry's relation to cognition was became central to remarks that followed. Prof. Adams noted that in Prof. Wang's poem the exegete tends to blend into the poet, and Prof. Krieger saw a sort of postmodern genre going from poetry to scholarship in, say, Nabokov, Borges, and others. Prof. Yu said that it was always assumed in China that a poem has a cognitive dimension.

Prof. Miller, at this point, wished to explore the problem of translation at a somewhat different level. He sensed that there may be in Prof. Wang' s poem allusions and actual quotations that as a Westerner he would entirely miss. He observed that he had heard a story of a meeting between two opposed Chinese war lords in which the whole conversation was one of exchange of lines of poetry from previous poems, a thing inconceivable in the U.S. or Europe. Prof. Wang then elucidated, though he said it was difficult to do so, some lines in his poem that were quotations. Prof. Miller observed that resonances of these can't carry over to the Western reader. Prof. Behler noted that this was a general problem, citing Paul Celan's poetry, which often sounded like German but was sometimes uninterpretable as German. Prof. Tay remarked that in the sixties' debate over Marxism between China and Russian one Chinese communique ended in lines of poetry almost certainly puzzling to Russian Sinologists but clearly comprehensible to the Chinese.

Prof. Adams observed with respect to the poet' s place that poetry seems to be seen as a very specialized form of discourse in the United States, partly because the university is the principal patron of poets today. They are in the institution but often express an otherness nevertheless. Prof. Behler observed that there is no presence of poetry in European humanistic discourse, but there is a theoretical discourse attempting to undermine the difference, and he cited both Derrida and Heidegger in this connection. Prof. Karatani spoke of difference in these matters between Japan and China. In a Japan for centuries heavily influenced by China, poetry and politics were not separable, though there was always tension. In the modern period there was a separation and a loss of valuable tension. Since about 1980 poets had lost power in a consumer culture. Many people write poems, often Haiku, but they are hardly poets. Prof. Pfeiffer briefly defended the Haiku as a poetic form. At this point Prof. Adams ended the session by remarking that the group had had the unique experience, probably never to be repeated, of hearing $\mathrm{C}$. H. Wang comment on a poem by Yang Mu. 